\title{
Coendangered hard-ticks: threatened or threatening?
}

\author{
Andrei Daniel Mihalca*, Călin Mircea Gherman and Vasile Cozma
}

\begin{abstract}
The overwhelming majority of animal conservation projects are focused on vertebrates, despite most of the species on Earth being invertebrates. Estimates state that about half of all named species of invertebrates are parasitic in at least one stage of their development. The dilemma of viewing parasites as biodiversity or pest has been discussed by several authors. However, ticks were omitted. The latest taxonomic synopses of non-fossil Ixodidae consider valid 700 species. Though, how many of them are still extant is almost impossible to tell, as many of them are known only from type specimens in museums and were never collected since their original description. Moreover, many hosts are endangered and as part of conservation efforts of threatened vertebrates, a common practice is the removal of, and treatment for external parasites, with devastating impact on tick populations. There are several known cases when the host became extinct with subsequent coextinction of their ectoparasites. For our synoptic approach we have used the IUCN status of the host in order to evaluate the status of specifically associated hardticks. As a result, we propose a number of 63 coendangered and one extinct hard-tick species. On the other side of the coin, the most important issue regarding tick-host associations is vectorial transmission of microbial pathogens (i.e. viruses, bacteria, protozoans). Tick-borne diseases of threatened vertebrates are sometimes fatal to their hosts. Mortality associated with pathogens acquired from ticks has been documented in several cases, mostly after translocations. Are ticks a real threat to their coendangered host and should they be eliminated? Up to date, there are no reliable proofs that ticks listed by us as coendangered are competent vectors for pathogens of endangered animals.
\end{abstract}

\section{Biodiversity or pest?}

In their review on tick-host specificity from 1982, Hoogstraal \& Aeschlimann wrote: "As biomedical researchers, we are charged with the task of improving the quality of human life and welfare precisely, reducing risks of disease, irritation, and debilitation resulting from parasitism by ticks" [1]. From strict medical point of view they might be questionably right. But, ticks, as all parasitic species, are part of global biodiversity which according to current trends should be preserved.

The overwhelming majority of conservation projects in the animal kingdom are focused on vertebrates, despite most of the species on Earth being invertebrates. Estimates state that about half of all named species of invertebrates are parasitic in at least one stage of their development [2]. The dilemma of viewing parasites as

\footnotetext{
*Correspondence: amihalca@usamvcluj.ro Department of Parasitology and Parasitic Diseases, University of Agricultural Sciences and Veterinary Medicine Cluj-Napoca, Calea Mănăştur 3-5, ClujNapoca, 400372, Romania
}

(c) 2011 Mihalca et al; licensee BioMed Central Ltd. This is an Open Access article distributed under the terms of the Creative Commons

biodiversity or pest has been discussed by several authors, regardless if it is about animal parasites [3-8]. General human perception of parasites is usually negative and several dictionaries derogatorily associate this concept with exploitation. Among all parasites, ticks, along with other ectoparasites seem to have one of the most negative reputations [9].

\section{Extant or extinct?}

Ticks (suborder Ixodida) are obligate blood-sucking acarines attacking a wide variety of hosts from all tetrapod vertebrate classes (Amphibia, Reptilia, Aves and Mammalia). Three families are currently recognized: Ixodidae (hard ticks), Argasidae (soft ticks) and Nuttalliellidae. The latest taxonomical synopses of the group [10-12] updated by [13] consider valid 700 non-fossil species in Ixodidae (for a review of fossil ticks see [14]). Though, how many of the 'non-fossil' species are still extant is almost impossible to tell, as many of them are 
known only from type specimens in museums and were never collected since their original description.

Generally, extinction is considered to have four main causes: habitat loss, species invasion, overkill and cascades of extinctions [15]. Cascades of extinctions (or coextinctions) are in most situations cases of habitat loss in species for which the habitat is another species, like the case of mutualists, commensals and parasites. In the case of most symbiotic interactions the extinction of the host could result in the extinction of several associated species [16]. Ticks are no exception.

\section{Narrow host specificity makes ticks co- endangered}

After the concept of 'coextinction was intuited by Darwin in 1862 and introduced in scientific literature in 1993 [17], the term 'coendangered' arose logically within the next years [18], when estimates stated that 6300 symbiotic species are coendangered with their associated organisms. Nevertheless, the review omitted several groups of parasites like protozoans, cestodes, trematodes, most nematodes, acanthocephalans, fleas, ticks, whale lice etc. Therefore, the number of coendangered parasites could be much higher. For ectoparasites, including ticks, not only the endangered status of the host makes them endangered. As part of conservation efforts of threatened vertebrates, actions often involve artificial breeding, re-introduction or relocations. During these processes, a common practice is the removal of external parasites, with devastating impact on their population [19]. Several cases are documented. One relevant example is of the louse Colpocephalum californici (now extinct) which were intentionally removed from the endangered California condor, Gymnogyps californianus during the captive breeding project at Los Angeles Zoo [20].

In the case of parasites, the coendangered status applies with predilection to species with high host-specificity. Ticks are distributed worldwide from the Arctic to tropical regions. Their geographical distribution is related to the range of their host(s) with the highest diversity in tropical regions. Host specificity in ticks is still a debated issue. In some tick species, the host specificity was evaluated by more or less complex experimental trials, but in the majority of the situations this label comes solely from field reports on tick-host associations. In the first situation, one of the most studied species is the cattle tick, Rhipicephalus (Boophilus) microplus. Several hypotheses were incriminated to explain host specificity in ticks: adaptation by the tick to the particular properties of host's skin, specific sensory stimulus to attachment, specific ability of the tick to evade the host's immune responses or dietary specificity [21-23]. Based on a review of experimental evidence or ecological observations, about $85 \%$ of the tick species are considered to have a certain degree of host specificity, especially in their adult stage [1]. However, sometimes ecological specificity (habitat dependence) could explain the apparent specific host association in ticks, reducing the access of certain tick species to a limited number of vertebrate species [24].

The first and single review so far on tick conservation [19] proposed 42 species of Ixodidae as candidates for the endangered status. Following this idea, the echidna tick Bothriocroton oudemansi was listed as coendangered with its host [25]. Similar opinions are available for other groups of parasites. The conservation status of myiasis causing Oestrid flies was discussed recently in detail [6]. In this review, the authors grouped the endangered parasitic flies into three categories, by the cause of possible extinction: treatment-induced, coextinction and neglected, listing a total number of 39 bot-flies. A synoptic review on coextinct lice of birds and mammals is also available [26].

\section{A synopsis of ticks proposed for coendangered status}

The International Union for Conservation of Nature (IUCN) classifies organisms into seven categories, according to their conservation status [27]. Additionally, some species have entries in the red list database, but their status is listed as data deficient. Furthermore, many species are not present at all in the IUCN database, meaning they have not been evaluated to date. For our synoptic approach we have used the IUCN status of the host in order to evaluate the status of specifically associated tick parasites, following the algorithm in Table 1. The list of valid ticks species used was according to the latest taxonomical reviews of the group $[10,11,13]$.

Extinction of single host species could result in the immediate extinction of several associated species (parasites, commensals, mutualists) [16]. In the case of Ixodidae, there are certain threatened vertebrates which host more than one tick species. For instance, the extinction of the sambar deer (Rusa unicolor) could lead to the coextinction of four specifically associated ticks. Moreover, ticks harbor themselves internal symbiotic microorganisms, most of them not studied. Thus, the resulted

Table 1 Algorithm used for proposal of tick conservation status

\begin{tabular}{cc}
\hline Proposed status of the tick & IUCN status of the host \\
\hline Extinct & EX, EW \\
\hline Coendangered & $C R, E N, V U$ \\
\hline
\end{tabular}

EX - Extinct; EW - Extinct in the Wild; CR - Critically Endangered; EN Endangered; VU - Vulnerable 
chain of extinctions is much more complex and difficult to estimate.

Our synoptic evaluation of ticks specifically associated with their threatened host revealed a number of 63 coendangered species (Tables 2 and 3).

Most species included in our review $(\mathrm{n}=31)$ belong to genus Amblyomma Koch, 1844. Their host specificity is high, especially in their adult stage [1] which makes them candidates for extinction if their hosts become extinct. Within the genus Ixodes, we propose 16 species, parasitic on tropical birds or mammals, as coendangered. All coendangered species $(\mathrm{n}=9)$ from the genus Haemaphysalis Koch, 1844 are restricted to Asian threatened mammals. Only three species of the genus Dermacentor Koch, 1844 are included in our synopsis. The genus Hyalomma Koch, 1844, parasitic on mammals and tortoises includes two coendangered species. The genus Bothriocroton Keirans, King and Sharrad, 1994, recently erected to genus level, was initially described as a subgenus of the former genus Aponomma (now synonym of Amblyomma) [12]. Seven species are currently included here, all with Australian distribution, with a single species coendangered (B. oedemansi). The monospecific genus Cosmiomma Schulze, 1919 is found on large threatened mammals from Africa, hence its single species, Cosmiomma hippopotamensis is considered coendangered.

\section{Coendangered ticks of reptiles}

Twenty species of coendangered ticks are proposed from those specifically associated with reptiles (Tables 2 and $3)$. Threatened chelonians harbor 12 of them (11 in the genus Amblyomma and 1 in the genus Hyalomma). Ten of these chelonian ticks are specifically associated with terrestrial species of the Testudinidae family. On the other hand, Amblyomma supinoi, which seems to have less host specificity, has all reported hosts being threatened chelonians (Testudinidae, Geoemydidae) from Asia. The only coendangered tick species of chelonians from Eurasia and Northern Africa is Hyalomma aegyptium, parasitic on tortoises of the genus Testudo. We can group the eight coendangered ticks of lizards into two major groups (all in the genus Amblyomma), based on the taxonomic and biogeographic data of their host: (i) ticks of Iguanidae endemic to West Indies and Galapagos and (ii) ticks of Varanidae from Indonesia.

\section{Coendangered ticks of birds}

Birds harbor five species which we list as coendangered. Four of them belong to the genus Ixodes and are nonquesting nest ticks parasitic on endangered or vulnerable birds; they were reported exclusively from island habitats (Tables 2 and 3). The Atlantic yellow-nosed albatross (Thalassarche chlororhynchos), which nests solely on a few islands from the Atlantic Ocean. is the only recorded host for two species of coendangered ticks. Two species of threatened kiwi birds (genus Apteryx) are the only known hosts of Ixodes anatis in New Zeeland. The fourth bird-associated Ixodes listed here as coendangered is Ixodes murreleti found specifically on the Xantus's murrelet (Synthliboramphus hypoleucus) in the Coronados Islands. The principal host of Amblyomma papuanum is the vulnerable flightless Southern cassowary (Casuarius casuarius) from Papua New Guinea.

\section{Coendangered ticks of mammals}

The 38 species of coendangered ticks associated with mammals belong to several genera (Table 2): Ixodes,

Table 2 Summary of Ixodidae (hard ticks) proposed to be considered coendangered

\begin{tabular}{ccccc}
\hline Genus & Number of valid species & Number of coendangered species & \multicolumn{2}{c}{ Host cathegory } \\
\cline { 3 - 5 } & & & Reptiles & Birds \\
Amblyomma & 130 & 31 & 19 & 1 \\
\hline Anomalohimalaya & 3 & 1 & - & - \\
\hline Bothriocroton & 7 & 1 & - & - \\
\hline Cosmiomma & 1 & 3 & - & - \\
\hline Dermacentor & 34 & 9 & - & - \\
\hline Haemaphysalis & 166 & 2 & - & - \\
\hline Hyalomma & 27 & 16 & 1 & - \\
\hline Ixodes & 243 & 0 & - & 4 \\
\hline Margaropus & 3 & 0 & - & - \\
\hline Nosomma & 2 & 0 & - & - \\
\hline Rhipicentor & 2 & 0 & - & - \\
\hline Rhipicephalus & 82 & 63 & - & - \\
\hline TOTAL & 700 & & 20 & - \\
\hline
\end{tabular}

a - Ixodes nitens which we list as extinct is not included 
Table 3 Host associations of Ixodidae proposed to be coendangered

\begin{tabular}{|c|c|c|c|}
\hline Species & Distribution & Main hosts & IUCN status of host \\
\hline \multirow[t]{2}{*}{ Ixodes anatis Chilton, 1904} & New Zeeland & Apteryx mantelli & EN \\
\hline & & Apteryx australis & $\mathrm{VU}$ \\
\hline \multirow[t]{2}{*}{ I. dendrolagi Wilson, 1967} & New Guinea & Dendrolagus matschiei & EN \\
\hline & & Dendrolagus dorianus & $\mathrm{VU}$ \\
\hline I. diomedeae Arthur, 1958 & Tristan da Cunha Islands & Thalassarche chlororhynchos & EN \\
\hline I. galapagoensis Clifford and Hoogstraal, 1980 & Galapagos & Aegialomys galapagoensis & $\mathrm{VU}$ \\
\hline I. lemuris Arthur, 1958 & Madagascar & Eulemur macaco & $\mathrm{VU}$ \\
\hline I. montoyanus Cooley, 1944K & South America & Pudu puda & $\mathrm{VU}$ \\
\hline I. moscharius Teng, 1982 & Tibet & Moschus berezovskii & EN \\
\hline I. moschiferi Nemenz, 1968 & Nepal, China & Moschus berezovskii & EN \\
\hline I. murreleti Cooley and Kohls, 1945 & Coronados Islands & Synthliboramphus hypoleucus & $\mathrm{VU}$ \\
\hline I. percavatus Neumann, 1906 & Tristan da Cunha Islands & Thalassarche chlororhynchos & EN \\
\hline I. schillingsi Neumann, 1901 & Africa & Colobus polykomos & $\mathrm{VU}$ \\
\hline I. stilesi Neumann, 1911 & Chile & Pudu puda & $\mathrm{VU}$ \\
\hline I. taglei Kohls, 1969 & Chile & Pudu puda & $\mathrm{VU}$ \\
\hline \multirow[t]{2}{*}{ I. tapirus Kohls, 1957} & Central and South America & Tapirus pinchaque & EN \\
\hline & & Tapirus bairdii & EN \\
\hline I. vestitus Neumann, 1908 & Australia & Myrmecobius fasciatus & EN \\
\hline I. zaglossi Kohls, 1960 & New Guinea & Zaglossus bruijni & $C R$ \\
\hline Haemaphysalis borneata Hoogstraal, 1971 & Malaysia & Rusa unicolor & $\mathrm{VU}$ \\
\hline H. capricornis Hoogstraal, 1966 & Thailand & Capricornis sumatraensis & $\mathrm{VU}$ \\
\hline H. goral Hoogstraal, 1970 & China & Nemorhaedus griseus & $\mathrm{VU}$ \\
\hline H. kopetdaghica Kerbabaev, 1962 & Asia & Capra aegagrus & $\mathrm{VU}$ \\
\hline H. moschisuga Teng, 1980 & China & Moschus berezovskii & EN \\
\hline H. pentalagi Pospelova-Shtrom, 1935 & Japan & Pentalagus furnessi & EN \\
\hline H. psalistos Hoogstraal, Kohls and Parrish, 1967 & Philippines & Rusa unicolor & $\mathrm{VU}$ \\
\hline H. sambar Hoogstraal, 1971 & India & Rusa unicolor & VU \\
\hline H. vietnamensis Hoogstraal and Wilson, 1966 & Asia & Rusa unicolor & VU \\
\hline Dermacentor circumguttatus Neumann, 1897 & Africa & Loxodonta africana & $\mathrm{VU}$ \\
\hline D. latus Cooley, 1937 & Central America & Tapirus bairdii & EN \\
\hline \multirow[t]{2}{*}{ D. rhinocerinus (Denny, 1843) } & Africa & Diceros bicornis & $C R$ \\
\hline & & Ceratotherium simum & NT \\
\hline \multirow[t]{2}{*}{ Hyalomma aegyptium (Linnaeus, 1758) } & Africa, Eurasia & Testudo graeca & $\mathrm{VU}$ \\
\hline & & Testudo horsfieldi & VU \\
\hline H. rhipicephaloides Neumann, 1901 & Middle East & Gazella gazella & $\mathrm{VU}$ \\
\hline Bothriocroton oedemansi (Neumann, 1910) & New Guinea & Zaglossus bruijni & $C R$ \\
\hline \multirow[t]{2}{*}{ Cosmiomma hippopotamensis (Denny, 1843) } & Africa & Hippopotamus amphibius & $\mathrm{VU} 0$ \\
\hline & & Diceros bicornis & $C R$ \\
\hline \multirow[t]{2}{*}{ Amblyomma albopictum Neumann, 1899} & West Indies & Cyclura lewisi & $C R$ \\
\hline & & Cyclura cornuta & $\mathrm{VU}$ \\
\hline \multirow[t]{3}{*}{ A. antillorum Kohls, 1969} & West Indies & Cyclura pinguis & $C R$ \\
\hline & & Iguana delicatissima & $\mathrm{VU}$ \\
\hline & & Cyclura carinata & EN \\
\hline A. argentinae Neumann, 1905 & Argentina & Chelonoidis chilensis & VU \\
\hline A. boeroi Nava et al., 2009 & Argentina & Catagonus wagneri & EN \\
\hline \multirow[t]{2}{*}{ A. chabaudi Rageau, 1964} & Madagascar & Pyxis arachnoides & EN \\
\hline & & Astrochelys radiata & EN \\
\hline
\end{tabular}


Table 3 Host associations of Ixodidae proposed to be coendangered (Continued)

\begin{tabular}{|c|c|c|c|}
\hline \multirow[t]{2}{*}{ A. clypeolatum Neumann, 1899} & \multirow[t]{2}{*}{ Asia } & Geochelone platynota & EN \\
\hline & & Indotestudo elongata & EN \\
\hline \multirow[t]{2}{*}{ A. coelebs Neumann, 1899} & \multirow[t]{2}{*}{ Central and South America } & Tapirus bairdii & EN \\
\hline & & Tapirus terrestris & $\mathrm{VU}$ \\
\hline A. crassum Robinson, 1926 & South America & Chelonoidis denticulata & $\mathrm{VU}$ \\
\hline A. crenatum Neumann, 1899 & Java & Rhinoceros sondaicus & $C R$ \\
\hline A. cruciferum Neumann, 1901 & West Indies & Cyclura cornuta & VU \\
\hline A. darwini Hirst and Hirst, 1910 & Galapagos & Amblyrhynchus cristatus & $\mathrm{VU}$ \\
\hline A. geochelone Durden, Keirans and Smith, 2002 & Madagascar & Astrochelys yniphora & $C R$ \\
\hline A. humerale Koch, 1844 & South America & Chelonoidis denticulata & $\mathrm{VU}$ \\
\hline A. incisum Neumann, 1906 & Central and North America & Tapirus terrestris & $\mathrm{VU}$ \\
\hline \multirow[t]{2}{*}{ A. javanense (Supino, 1897) } & \multirow[t]{2}{*}{ Asia } & Manis javanica & EN \\
\hline & & Manis pentadactyla & EN \\
\hline A. komodoense (Oudemans, 1929) & Indonesia & Varanus komodoensis & $\mathrm{VU}$ \\
\hline A. latepunctatum Tonelli-Rondelli, 1939 & South America & Tapirus terrestris & $\mathrm{VU}$ \\
\hline A. macfarlandi Keirans, Hoogstraal and Clifford, 1973 & Galapagos & Chelonoidis nigra & $\mathrm{VU}$ \\
\hline A. multipunctum Neumann, 1899 & South America & Tapirus sp. & ENNU' \\
\hline A. papuanum Hirst, 1914 & Australia & Casuarius casuarius & $\mathrm{VU}$ \\
\hline A. personatum Neumann, 1901 & Africa & Diceros bicornis & $C R$ \\
\hline A. pilosum Neumann, 1899 & Galapagos & Chelonoidis nigra & $\mathrm{VU}$ \\
\hline A. postoculatum Neumann, 1899 & Australia & Lagostrophus fasciatus & EN \\
\hline \multirow[t]{2}{*}{ A. rhinocerotis (de Geer, 1778) } & \multirow[t]{2}{*}{ Africa } & Diceros bicornis & $C R$ \\
\hline & & Ceratotherium simum & NT \\
\hline A. robinsoni Warburton, 1927 & Indonesia & Varanus komodoensis & $\mathrm{VU}$ \\
\hline \multirow[t]{3}{*}{ A. supinoi Neumann, 1905} & \multirow[t]{3}{*}{ Asia } & Indotestudo elongata & EN \\
\hline & & Heosemys spinosa & EN \\
\hline & & Heosemys depressa & $C R$ \\
\hline A. tholloni Neumann, 1899 & Africa & Loxodonta africana & VU \\
\hline A. torrei Perez Vigueras, 1934 & West Indies & Cyclura lewisi & $C R$ \\
\hline A. tuberculatum Marx, 1894 & USA & Gopherus polyphemus & $\mathrm{VU}$ \\
\hline A. usingeri Keirans, Hoogstraal and Clifford, 1973 & Galapagos & Chelonoidis nigra & $\mathrm{VU}$ \\
\hline A. williamsi Banks, 1924 & Galapagos & Conolophus subcristatus & $\mathrm{VU}$ \\
\hline
\end{tabular}

1 - The host for A. multipunctum was listed only as Tapirus sp. Only four species of genus Tapirus are known, three of which are endangered and one vulnerable. CR - Critically Endangered; EN - Endangered; VU - Vulnerable; NT - Near Threatened

Haemaphysalis, Dermacentor, Hyalomma, Bothriocroton, Cosmiomma and Amblyomma.

Two species are parasitic on an egg-laying mammal, the critically endangered Western long-beaked echidna (Zaglossus bruijnii) in New Guinea. The other three species are found on threatened marsupials from Australia or New Guinea. South and Central American tapirs (genus Tapirus) are hosts to six coendangered ticks in the genera Ixodes, Dermacentor and Amblyomma. Seven species of ticks are specific parasites of elephants, rhinoceros and hippopotamus. Although the distribution range of these hosts is still wide, antiparasitic treatments during translocations pose a large problem to the survival of associated ticks [19]. Several threatened South
American and Asian even-toed ungulates (order Artiodactyla) are specific hosts to 15 species of coendangered ticks. Five additional coendangered tick species are each parasitic on species from five other mammalian orders. Ixodes galapagoensis on a rodent in Galapagos, Ixodes lemuris on a lemur in Madagascar, Ixodes schillingsi on a primate in Africa, Haemaphysalis pentalagi on a lagomorph in Japan and Amblyomma javanense on pangolins in Asia.

\section{Extinct ticks}

Ticks described from fossil deposits are omitted. We consider extinct one species, namely Ixodes nitens, described from two female ticks collected on Rattus 
macleari on Christmas Island. The last report of the host species was in 1903 [28]. As the other endemic rat species Rattus nativitatis (sympatric with $R$. macleari), did not harbor I. nitens, we can assume this tick was specifically associated with its type host. Thus, we exclude the possibility that $I$. nitens might have readapted as a parasite of the introduced black rats, Rattus rattus [29]. However, no direct evidence is available.

\section{Are endangered hosts endangered because of ticks?}

Probably the most important issue regarding tick-host associations is vectorial transmission of microbial pathogens. Ticks are able to transmit viruses, bacteria and protozoans to a variety of hosts. One of the most pathogenic tick-borne microbes are piroplasms (genera Babesia and Theileria). The potential impact of babesiosis on conservation actions was discussed mainly as a consequence of stress-mediated relapse of chronic infections during translocation [30]. Otherwise, tickborne diseases of threatened vertebrates are rarely fatal to their hosts. The following accounts consider only reports from hosts of coendangered ticks. Mortality associated with pathogens (Babesia bicornis and Theileria bicornis) acquired from ticks has been documented in black rhinoceros in Tanzania and South Africa [31-34]. The specific vector for these two haemoprotozoans is not known, but Dermacentor rhinocerinus and Amblyomma rhinocerotis were suggested [34]. Hence, extinction of these ticks is expected to result in the eradication of disease caused by B. bicornis and $T$. bicornis. A recent study from South Africa showed that $36.41 \%$ white rhinoceros were infected with Theileria bicornis and $9.23 \%$ with Theileria equi [35]. However, no pathology associated with the infection was recorded in white rhinoceros. Babesia loxodontis was described from asymptomatic African elephants, Loxodonta africana [36]; babesiosis in Asian elephants can be associated with weakness, fever, jaundice, constipation and haemoglobinuria [37]. Babesia pattoni was reported in Rusa unicolor but no associated pathology was described [38].

So far, no tick-borne diseases with impact on the health of threatened birds or reptiles have been described. Asymptomatic infections with Hemolivia mauritanica have been reported in Testudo graeca over its distribution range [39]. The zoonotic bacterial pathogen Anaplasma phagocytophilum have been isolated in ticks Amblyomma flavomaculatum collected on monitor lizards (Varanus exanthematicus) [40]. Although neither the host nor the ticks are endangered, there is high probability that other Amblyomma species could transmit Anaplasma to lizards of genus Varanus.

\section{Conclusions}

Expectedly or not, we came back to the question of Hoogstraal and Aeschlimann from the beginning of this paper. Should we decide on conservation of rare ticks? Or are they a real threat to their coendangered host and should be eliminated? Ticks as such are not dangerous. Disease, if present, is in most of the situations caused by vectored microbes. Moreover, pathology induced by tick-borne diseases in wild animals is seldom dangerous and is usually related to supplemental stressing factors (i.e. translocation). Last but not least, there is no proof to date that ticks listed by us as coendangered are competent vectors for pathogens of endangered animals.

Nevertheless, IUCN should reconsider the criteria of indexing species in its database as threatened. All symbiotic species (mutuals, commensals, parasites) specifically associated with their host should be listed as coendangered. As previously suggested [3], some host-specific parasites are more endangered than their host. Moreover, parasites have their own evolutionary importance, and as suggested even in the early 1990's, parasites should have equal rights with their host [3,5].

\section{Acknowledgements}

The publication of this paper was supported from grant IDEI-PCCE CNCSIS $84,7 / 2010$.

\section{Authors' contributions}

ADM - the idea of the manuscript, the intellectual content and wrote the text, reference on reptiles; CMG - reference research on part of the mammals and birds; VC - reference research on mammals and contributed to the text writing, mainly the piroplasm related paragraphs. All authors read and approved the final manuscript.

\section{Competing interests}

The authors declare that they have no competing interests.

Received: 10 March 2011 Accepted: 9 May 2011 Published: 9 May 2011

\section{References}

1. Hoogstraal H, Aeschlimann A: Tick-host specificity. Mitt Schweiz Entomol Ges 1982, 55:5-32.

2. Windsor DA: Most of the species on Earth are parasites. Int J Parasitol 1998, 28:1939-1941.

3. Rózsa L: Points in question. Endangered parasite species. Int J Parasitol 1992, 22:265-266.

4. Bush $\mathrm{AO}$, Kennedy $\mathrm{CR}$ : Host fragmentation and helminth parasites: hedging your bets against extinction. Int J Parasitol 1994, 24:1333-1343. Windsor DA: Equal rights for parasites. Conserv Biol 1995, 9:1-2.

6. Colwell DD, Otranto D, Stevens JR: Oestrid flies: eradication and extinction versus biodiversity. Trends Parasitol 2009, 25:500-504.

7. Pérez JM: Parasites, pests, and pets in a global world: new perspectives and challenges. J Exot Pet Med 2009, 18:248-253.

8. Pizzi R: Veterinarians and taxonomic chauvinism: the dilemma of parasite conservation. J Exot Pet Med 2009, 18:279-282.

9. Waudby HP, Petit S, Weber D: Human perception and awareness of ticks in a South Australian rural community and implications for management of Amblyomma triguttatum triguttatum. Exp Appl Acarol 2008, 45:71-84.

10. Barker SC, Murrell A: Systematics and evolution of ticks with a list of valid genus and species names. In Ticks: Biology, Disease and Control. Edited by: Bowman AS, Nuttall PA. Cambridge: University Press; 2008:1-39. 
11. Guglielmone AA, Robbins RG, Apanaskevich DA, Petney TN, Estrada-Peña A, Horak IG: Comments on controversial tick (Acari: Ixodida) species names and species described or resurrected from 2003 to 2008. Exp Appl Acarol 2009, 48:311-327.

12. Kolonin GV: Fauna of Ixodid Ticks of the World.[http://www.kolonin.org].

13. Guglielmone AA, Robbins RG, Apanaskevich DA, Petney TN, Estrada-Peña A, Horak IG, Shao R, Barker SC: The Argasidae, Ixodidae and Nuttalliellidae (Acari: Ixodida) of the world: a list of valid species names. Zootaxa 2010, 2528:1-28.

14. de la Fuente J: The fossil record and the origin of ticks (Acari: Parasitiformes: Ixodida). Exp Appl. Acarol 2003, 29:331-344.

15. Diamond JM: Overview of recent extinctions. In Conservation for the twenty-first century. Edited by: Western D, Peral M. Oxford: University Press; 1989:37-41.

16. Dunn RR, Harris NC, Colwell RK, Koh LP, Sodhi NS: The sixth mass coextinction: are most endangered species parasites and mutualists? Proc R Soc B Biol Sci 2009, 276:3037-3045.

17. Stork N, Lyal CH: Extinction or 'co-extinction' rates? Nature 1993, 366:307.

18. Koh LP, Dunn RR, Sodhi NS, Colwell RK, Proctor HC, Smith VS: Species coextinctions and the biodiversity crisis. Science 2004, 305:1632-1634.

19. Durden LA, Keirans JE: Host-parasite co-extinction and the plight of tick conservation. Am Entomol 1996, 42:87-91.

20. Dunn RR: Coextinction: anecdotes, models, and speculation. In Holocene Extinctions. Edited by: Turvey ST. Oxford: University Press; 2009:167-180.

21. Willadsen P: Immunity to ticks. Adv Parasitol 1980, 18:293-313.

22. Waladde SM, Rice MJ: The sensory basis of tick feeding behaviour. In Physiology of ticks. Edited by: Obenchain FD, Galun R. Oxford: Pergamon Press; 1982:71-118.

23. Willadsen $\mathrm{P}, \mathrm{Kemp} \mathrm{DH}$, McKenna MJ: Bloodmeal ingestion and utilization as a component of host specificity in the tick, Boophilus microplus. $Z$ Parasitenkd 1984, 70:415-420.

24. Nutting WB: Host specificity in parasitic acarines. Acarologia 1968, 10:165-180.

25. Beati L, Keirans JE, Durden LA, Opiang LA: Bothriocroton oudemansi (Neumann, 1910) n. comb. (Acari: Ixodida: Ixodidae), an ectoparasite of the western long-beaked echidna in Papua New Guinea: redescription of the male and first description of the female and nymph. Syst Parasitol 2008, 69:185-200.

26. Mey E: Psittacobrosus bechsteini: ein neuer ausgestorbener Federling (Insecta, Phthiraptera, Amblycera) vom Dreifarbenara Ara tricolor (Psittaciiformes), nebst einer annotierten Übersicht über fossile und rezent ausgestorbene Tierläuse. Anz Ver Thüring Ornithol 2005, 5:201-217.

27. The IUCN Red List of Threatened Species. [http://www.iucnredlist.org/]

28. Lamoreux J: Rattus macleari. 1934 [http://www.iucnredlist.org/apps/redlist/ details/19344/0]

29. Wyatt KB, Campos PF, Gilbert MT, Kolokotronis SO, Hynes WH, DeSalle R, Daszak P, MacPhee RD, Greenwood AD: Historical Mammal Extinction on Christmas Island (Indian Ocean) Correlates with Introduced Infectious Disease. PLoS One 2008, 3:e3602.

30. Penzhorn BL: Babesiosis of wild carnivores and ungulates. Vet Parasitol 2006, 138:11-21.

31. Brocklesby DW: A Babesia species of the black rhinoceros. Vet Rec 1967, 80:484.

32. Mugera GM, Wandera JG: Degenerative polymyopathies in East African domestic and wild animals. Vet Rec 1967, 80:410-413.

33. McCulloch B, Achard PL: Mortalities associated with the capture, translocation, trade and exhibition of black rhinoceroses Diceros bicornis. Int Zoo Yearb 1969, 9:184-195.

34. Nijhof AD, Penzhorn BL, Lynen G, Mollel JO, Morkel P, Bekker CPJ, Jongejan F: Babesia bicornis sp. nov. and Theileria bicornis sp. nov.: tickborne parasites associated with mortality in the black rhinoceross (Diceros bicornis). Journal of Clinical Microbiology 2003, 41:2249-2254.

35. Govender D: Detection of Babesia and Theileria parasites in white rhinoceroses (Ceratotherium simum) in the Kruger National Park, and their relation to anaemia. MS Thesis University of Pretoria, Faculty of Veterinary Sciences; 2009.

36. Levine ND: The Protozoan Phylum Apicomplexa. Volume // Boca Raton: CRC Press; 1988

37. Fowler ME: Parasitology. In Biology, medicine, and surgery of elephants. Edited by: Fowler ME, Mikota SK. Ames, lowa: Blackwell Publishing; 2006:159-181.
38. Dissanaike AS: On some blood parasites of wild animals in Ceylon. Ceylon Vet J 1963, 11:73.

39. Široký $P$, Mikulíček $P$, Jandzík D, Kami H, Mihalca AD, Rouag R, Kamler M, Schneider C, Záruba M, Modrý D: Co-distribution pattern of a haemogregarine Hemolivia mauritanica (Apicomplexa: Haemogregarinidae) and its vector Hyalomma aegyptium (Metastigmata: Ixodidae). J Parasitol 2009, 95:728-733.

40. Nowak M, Cieniuch S, Stańczak J, Siuda K: Detection of Anaplasma phagocytophilum in Amblyomma flavomaculatum ticks (Acari: Ixodidae) collected from lizard Varanus exanthematicus imported to Poland. Exp Appl Acarol 2010, 51:363-371.

doi:10.1186/1756-3305-4-71

Cite this article as: Mihalca et al:: Coendangered hard-ticks: threatened or threatening? Parasites \& Vectors 2011 4:71.

\section{Submit your next manuscript to BioMed Central and take full advantage of:}

- Convenient online submission

- Thorough peer review

- No space constraints or color figure charges

- Immediate publication on acceptance

- Inclusion in PubMed, CAS, Scopus and Google Scholar

- Research which is freely available for redistribution

Submit your manuscript at www.biomedcentral.com/submit
Biomed Central 